\title{
Тетяна Кароєва
}

Вінницький державний педагогічний університет ім. Михайла Коцюбинського доктор історичних наук, доцент (Україна)

$$
\text { e-mail: urasim@i.ua }
$$

https://orcid.org/0000-0001-5012-9513

ResearcherID: https://publons.com/researcher/3301742/tetiana-karoyeva/

\section{Фрондерські настрої помісного дворянства Правобережної України другої половини XIX ст. крізь призму книжковиХ практик}

Анотація. Мета статmi. 3 модернізацією Російської імперії помісне дворянство впродовж другої половини XIX cm. поступово адаптувалося до нових соціоекономічних умов $i$ ставало соціально активнішим, втім, не отримало навіть мінімальних політичних регуляторів для задоволення своїх соціальних, економічних і культурних потреб до 1906 р., виборів у Державну думу. Воно, як й усі інші соціальні групи імперії, не могло формулювати своїх політичних вимог, створювати політичні організації, які б відстоювали їхні інтереси. Водночас й до револючійних подій 1917 р. дворянство продовжували вважати опорою самодержавства, тому важливо визначити, чи було воно абсолютно відданим імперії, чи існували фррондерські настрої серед його представників. Під фррондерськими настроями певної соціальної групи тут розуміється негативізм, викликаний діями влади, який реалізується скоріше як культурницький опір і не веде до конфронтації з владою. Помісне дворянство розглядається поза етнічною приналежністю його представників. Методологія дослідження передбачає використання книг як речових джерел та історико-книгознавчі методи аналізу. Наукова новизна. До вивчення пасивного опору владі, традиційно малодоступного для студіювання, залучений аналіз книжкових практик (придбання, поширення, використання та зберігання книг) помісного дворянства. Висновки. З'ясовано, що упродовж другої половини XIX cm. поміщики-дворяни Правобережної України мали фррондерські настрої. Поліиійний характер державного апарату країни примушував навіть лояльних підданих вдаватися до протиправних дій для задоволення своїх культурних потреб. Їхні свідомі практики щодо заборонених книг свідчать про тихий спротив владі, який врештірешт протиставляв людину державній системі, розхитував традиційну систему цінностей.

Ключові слова: помісне дворянство, книжкові практики, книга, книжкова культура, родові бібліотеки, Правобережна Україна

Постановка проблеми. У Російській імперії й до революційних подій 1917 р. дворянство вважалося опорою самодержавства, втім упродовж другої половини XIX ст. 3 ним, особливо помісним, відбулися значні метаморфози. Криза і відміна кріпосницької системи господарювання вибили з-під нього ґрунт для кріпосницького традиціоналізму, створили певний психологічний дискомфорт, змусили тих, хто залишився в маєтках, мислити і господарювати по-іншому, але не дали реального політичного інструменту вирішення проблем, що постали в нових соціоекономічних реаліях. Політична можливість впливу помісного дворянства на події в країні з'явилася лише у 1906 р., з виборами в Державну думу Російської імперії. Загалом, вочевидь, дворяни воліли залишатися в своєму соціальному середовищі, користуватися всіма привілеями, наданими їм владою, були лояльними до неї, але загальне незадоволення ситуацією, коли вони не могли офіційно впливати на події в країні, мало якось проявлятися. У статті пропонується цей побутовий негативізм до влади, який реалізується скоріше як культурницький опір і не веде до конфронтації з владою, називати фрондерськими настроями. Зауважимо, помісне дворянство розглядається поза етнічною приналежністю його представників.

Специфріка інтелектуального життя дворянства Правобережної України полягала в тому, що тут просвітницькі ідеї почали поширюватися раніше і проникли глибше. Під їх впливом читання вважалося обов'язковою складовою виховання дворянської дитини, до того ж й модернізаційні процеси в країні вимагали від людини певного інтелектуального рівня. Книги увійшли в повсякденний побут помісного дворянства. Як уже було встановлено, з врахуванням рівня заможності та сталого володіння і проживання в маєтку, на кінець XIX ст., наприклад, в маєтках на території Подільської губернії могло бути від 300 до 619 родових бібліотек, напередодні Першої світової війни - близько 390 [Кароєва, 2019 : 151]. Безумовно, з одного боку, частина заможних землевласників не цікавилася книжками, 3 іншого - поодинокі представники малопомісного дворянства, які мали обмежені статки, могли також формувати власні книгозбірні. 
Аналіз джерел та останніх досліджень. Традиція вивчення дворянства як окремого соціального стану пореформеної доби на українських теренах має давнє коріння. Ще у дореволюційний період дослідники почали вивчати соціально-економічну трансформацію дворянства, його меценатську та культурну діяльність, історію окремих родин та осіб. Радянські історики акцентували увагу на соціально-економічних аспектах існування цього стану, щоб довести його занепад. Сучасні дослідження переважно заперечують цю позицію радянських дослідників. Науковці зазначають, що частина представників цього суспільного стану намагалася пристосуватися до нових капіталістичних умов. За радянський період вивчення специфіки опозиційних поглядів дворянства як страти не вважалося доцільним, розглядалися переконання лише окремих представників з позицій певних ідеологій. Сучасні українські (О. Барвінок [Барвінок, 2014], І. Кривошея [Кривошея, 1997], Н. Темірова [Темірова, 2003], Т. Шахрай [Шахрай, 2009]) та російські (Е. Баринова [Баринова, 2006], К. Курков [Курков, 2006], Т. Філатова [Филатова, 2000], Е. Юдін [Юдін, 2000]) історики більше уваги приділяють соціокультурній адаптації дворянства у пореформений період, акцентуються на зменшенні престижу та ролі стану в суспільстві, на еволюції його етичних норм й уявлень, спробах участі в легальній політичній діяльності.

Ученим простіше вивчати відкритий опір, який знаходить відображення в документах як представників владної сторони, так й фріксується самими учасниками боротьби. Пасивний опір відстежити набагато складніше через його прихованість, розмитість, свідоме уникання людьми демонстрації своїх настроїв. Традиційними джерелами такої інформації є мемуари, листування, втім, про опозиційні настрої можуть свідчити й книжкові практики. Наприклад, як вже раніше було з'ясовано [Соломонова, 2010 : 331], польське дворянство аби забезпечити релігійне життя та навчання польською мовою купували дешеві польські видання і роздавали їх селянським дітям, купували заборонені польські друки, утримували таємні громадські бібліотеки, зберігали книги«меморії», пов'язані з постатями польських борців за незалежність, особливо з власних родин. Відкритим залишається питання, чи існував серед представників помісного дворянства опір державі поза національним питанням.

Історики Р. Шарт'є [Шартье, 2001], Р. Дарнтон [Darnton, 2010], що вивчали культурні витоки Французької революції 1789 р., звернули увагу на те, яку роль відіграло друковане слово у формуванні громадської думки. Хоча Р. Шартьє вважає натяжкою напряму виводити думки людей з кола їхнього читання, він зазначає, що умонастрої зазнають вирішальних змін до підйому критичної літератури, і саме ці зрушення в свідомості викликають пекучий інтерес до неї [Шартье, $2001: 217$ ]. Тобто література, на його думку, сприяє розхитуванню звичної системи координат, розвінчанню традиційних цінностей та існуючого політичного ладу. У цьому контексті важливо з'ясувати за допомогою вивчення книжкових практик представників помісного дворянства, чи існував серед них інтерес до критичної літератури, чи були фрондерські настрої серед них. Це й є метою статті. Основним джерелом дослідження є історико-книжкові колекції з маєткових бібліотек, що зберігаються сьогодні у фондах відділу рідкісних і цінних видань Вінницької ОУНБ ім. К. А. Тімірязєва (далі - відділ РіЦ).

Виклад основного матеріалу. До книжкових практик віднесемо свідомі дії щодо придбання, поширення, використання та зберігання книг, тобто як і які купували книги, як їх читали та зберігали, чи давали їх читати іншим. Мова тут йде про книги, зміст яких, на думку влади, міг загрожувати суспільному порядку, релігії та моралі. Владні структури завжди прагнули вилучити з друкованої продукції все, що могло нашкодити ії̈ статусу, а зацікавлені читачі навпаки намагалися мати доступ до будь-якої інформації. Ще Статутом про цензуру 1828 р. було визначено, що в Російській імперії власники книгозбірень могли мати лише дозволені цензурою книги [ПСЗ. Собр. 2. Т. 3. № 1979]. Контроль за фондами маєткових книгозбірень покладався на повітових справників або їхніх заступників. Чиновники мали особисто переглядати книги. Зрозуміло, що маючи завантаження безпосередньою роботою, приділяти належну увагу родовим кількатисячним збіркам, вони не мали можливості, тому власники книгозбірень могли мати друки будь-якого змісту.

Закономірно виникає питання, як потрапляли подібні видання в маєткові бібліотеки. Друкувати в Російській імперії недозволені книги можна було лише нелегально, відповідно так само вони мали поширюватися. Малоймовірно, що представники в цілому лояльного до влади помісного дворянства будуть мати системну співпрацю з нелегалами. У них як представників привілейованого стану, достатньо заможних, щоб їздити за кордон, була інша шпарина, що дозволяла урізноманітнювати коло читання, - придбання книг за кордоном.

За російським законодавством книги, надруковані за кордоном, мали проходити цензурний огляд. Тим самим Статутом 1828 р. було визначено, що видання, призначені для книжкової торгівлі, з Петербурзької, Кронштадської, Брестської та Радзивилівської митниць направлялися в Комітет цензури іноземної (Петербург), де й вирішувалася їхня подальша доля [ПС3. Собр. 2. Т. 3. № 1979]. Приватні особи (російські піддані та іноземні мандрівники), 
перетинаючи кордон, давали підписку про пред'явлення ввезених книг в установи іноземної цензури (на українських теренах - Одеський комітет). 31843 р. термін пред'явлення книг був тримісячним. Цензори комітету звіряли книги з каталогами дозволених іноземних видань і цензурували невідомі для них друки. Загалом всі книги ділилися на 4 категорії: дозволені в цілому; дозволені з виключенням окремих місць (заборонені сторінки зафрарбовувалися чорним чорнилом) або вирізанням окремих сторінок; заборонені для публіки (могли видаватися лише благонадійним особам, які давали розписку лише про «особисте» використання видань; заборонені безумовно (книги видавалися лише з дозволу імператора) [Патрушева, 2013 : 5356]. 31864 р. митниці отримали право видавати мандрівникам їх власні книги (крім політичних, релігійних і порнографрічних) в одному примірнику без участі іноземної цензури: пам'ятні книжки, альманахи, календарі, словники, романи, повісті та оповідання, плани, карти, путівники, ноти, а також молитовники і книги Святого Письма, крім надрукованих за кордоном російською або церковнослов'янською мовами [ПСЗ. Собр. 2. Т. 39. № 41 224].

Зрозуміло, що тут у мандрівників було багато можливостей провезти книгу будь-якого змісту. Самі чиновники до провозу книг іноземними мовами ставилися поблажливо. Вважалося, що читати іноземними мовами може незначна кількість населення, як правило, лояльно налаштованого до існуючого ладу [Брискман, $1935: 570]$.

Ще одним способом отримання забороненої літератури могло бути звернення до контрабандистів або перевірених книгарів. Обидва варіанти були доволі проблематичними: перший, оскільки контрабандистам треба було замовляти конкретні видання; другий, оскільки з книгарями, переважно з великих міст, потрібно було підтримувати постійний контакт. Книгарі у повітах не мали достатньої кількості клієнтів на подібну літературу і були надто помітними. Книгарі з великих міст не могли тримати тривалий час нелегальні видання, очікуючи на клієнта, а довіряти їх пошті було надто ризикованим.

Отже, мабуть, особисте ввезення безцензурної книги було основним способом ії отримання.

Уже з 1840-х рр. у краї ширилися чутки про читання нелегальної літератури, про те, що якась поміщиця «читає у деяких знайомих пасквільні вірші», що з обшуків виявлено книги «обурливого змісту» або ж «альбоми з обурливими віршами» [Левицкий, 1906 : 73].

За фоондом відділу РіЦ, в маєткових книгозбірнях Правобережної України були, насамперед, видання широкого викривального змісту. Наприклад, твори землячки $Є$. Радзивілл (уродж. Жевуської) під псевдонімом «Comte Paul Vasili» - скандальна серія про вищий світ європейських столиць, зокрема російської, свого роду чорний піар, що виставляв багатьох аристократичних осіб у негативному світлі: «La sociéte de Berlin» (Париж, 1884), «La Société de Saint-Pétersbourg» (Париж, 1886). Дворянсько-опозиційне ставлення виражали книги І. Головіна та князя П. Долгорукова (за те, як вони викривали рід Романових та російську аристократію, імператор Микола I позбавив І. Головіна дворянства і чинів, засудив на каторгу, а імператор Олександр II позбавив П. Долгорукова князівського титулу, статків і засудив на довічне вигнання з Росіï). Твори I. Головіна «La Russie sous Nicolas I» (Париж, Лейпциг, 1845), П. Долгорукова «La Verite sur la Russie» (Париж, 1861), «Memoires» (Женева, 1867) переходили з рук до рук, про що свідчать маргіналії, численні підкреслення різними олівцями. Як писав російський літературознавець Н. Ейдельман: «У 1860-х рр. ім'я Долгорукова для багатьох друзів і ворогів стояло поруч, мало не нарівні з Герценом. Більш того, в якомусь сенсі вищі влади боялися Долгорукова навіть більше, ніж Іскандера» [Эйдельман, $1984: 256]$. Інтерес до праць Іскандера (О. Герцена) також засвідчується наявністю його видань. 3 немирівського зібрання Б. Потоцького-Г. Строганова походить відбиток статті О. Герцена про Дж. Ґарібальді «Сатісіа rossa» (Брюссель, 1865) з газети «Колокол» під псевдонімом «Іскандер» (до речі, на корінці книги ані автора, ані назви).

Наукові розвідки з історії революційного руху також перехоплювала цензура, що не завадило Б. Потоцькому мати монографрію Луї Блана «Histoire de dix ans. 1830 - 1840» (5 т., Париж, 1841-1844), Здзеховським - її ж брюссельське перевидання 1847 р. Це перший соціалістичний твір, який отримав поширення в Російській імперії після ідей сенсімонізму. По ознайомленню з ним читачі починали осмислення класового змісту революції 1830 р. у Франції, ролі буржуазії та капіталізму в історії. Автор доволі швидко отримав європейську славу завдяки своєму різко викривальному тону щодо дій фрранцузького уряду.

Менш виразно, але також показово, про існування фрондерських настроїв свідчить читання художніх творів, заборонених до поширення або перекладу в країні. Приміром, Вольтер - як в оригіналі, так і в перекладі - відомий у Російській імперії та Речі Посполитій автор ще $з$ XVIII ст., проте цензура час від часу переслідувала його публікації, особливо антиклерикальні. Тим не менш у книгозбірні Руссановських з Якушинців була перша частина фрілософрського лексикону Вольтера («Oeuvres complétes», т. 16, Париж, 1876), забороненого у Росії в 1883 p. 
Виключний успіх творів В. Гюго у Франції також дуже рано отримав у Російській імперії гучний та тривалий резонанс. Особливо гостро сприймалися на тлі російської дійсності ноти соціального протесту, що звучали вже в ранніх творах письменника. Ще у 1834 р. цензурою було заборонено передрук п'єси «Lucrèce Borgia», розміщення будь-яких уривків з неї, втім, в одній з подільських дворянських книгозбірень був том драматичних творів «Théatre» (Париж, 1844), до складу якого увійшла ця п'єса. Роман «Les Misérables» цензура розглядала 1862 р. у зв'язку з тогорічним брюссельським зібранням творів В. Гюго та дозволила з вилученням деяких уривків на її вказівку, адже попередні частини вже отримали дозвіл. Через кілька місяців роман заборонений до перекладу з фрормулюванням, що «останні томи роману мають найбільш шкідливе спрямування» [Айзеншток, $1939: 789$ ]. Однак з тієї ж бібліотеки Руссановських походить його лейпцизьке видання $1862 \mathrm{p}$.

Попри загальну популярність Жорж Санд в Росії іï романи «Le Piccinino» (Брюсcель, 1847), «Histoire de ma vie» (Париж, 1855) також були заборонені до поширення та подальшого перекладу [Айзеншток, 1939 : 813]. Однак примірники обох дісталися подільської землі.

Зберігаючи заборонені видання у палацових бібліотеках, їх власники постійно ризикували бути звинуваченими в протиправних діях. 3 огляду на зрозумілу утаємниченість цих дій складно сьогодні міркувати про систему переховування чи зберігання таких примірників. Серед доступних джерел $є$ зовнішній вигляд книг, який свідчить про намагання власників уникнути зайвої уваги до них. Так, жодний з чотирьох примірників збірника дипломатичних документів «Recueil des traites et conventions concernant la Pologne, 1762 - 1862» (Париж, 1862), укладеного графом Д'Ангебергом (псевдонім Л. Ходзька), з родових бібліотек Руссановських з Якушинців, Собанських з Ободівки, Якубовських з Люлинців і Ярошинських з Дзвонихи не мав повної назви на корінці палітурки, хоча обсяг книги у 1172 сторінки дозволяв. Примірник Ярошинських містив напис «Recueil des traites et conventions concernant» без автора, на решті було зазначено автора та слово «Pologne». Так само на двох примірниках книги І. Головіна «La Russie sous Nicolas I» позначено лише «La Russie» без автора. Своєрідно інтерпретовано також авторство $€$. Радзивілл як «Р. Vasili».

Подільські читачі добре усвідомлювали, видання якого змісту вони купують, адже, про всяк випадок, на корінцях примірників Луї Блана $є$ назва, а його прізвище відсутнє. I навпаки з художніми творами згадуваних популярних авторів: на корінці $є$ тиснення прізвища автора, а от назва твору відсутня.

Іноді поміщики прагнули взагалі уникати зайвої уваги до складу фондів бібліотек. Наприклад, Я. Маньковський з Саїнки платив поліцейському чиновнику, який оглядав його бібліотеку, щоб той «не бачив» певних видань [Epsztein, 2005 : 64-65]. Так само з місцевими приставами «домовлялися» й інші дідичі [Kutyłowska, 2003 : 22; Epsztein, 2005 : 64-65], хоча ці відомості більше стосуються вже рубежу століть. За спогадами, у цей час дехто з поміщиків привозив заборонені видання не тільки для себе, а й для поширення. Так неодноразово вчиняв B. Іванський з Вільшанки [Epsztein, $2005: 65]$. Пізніше у 1905 р. дехто 3 поміщиків передплачував подільську україномовну газету «Світова зірниця» і безкоштовно ії роздавав місцевим селянам [Epsztein, 2005 : 64-65].

I взагалі на початку XX ст., особливо після революційних подій 1905-1907 рр., коли змінилися політична ситуація в країні, цензурні вимоги, то й книжкові практики набули дещо іншого вигляду.

Висновки. 3 огляду на книжкові практики помісне дворянство другої половини XIX ст., яке російське самодержавство продовжувало вважати своєю опорою, мало фрондерські настрої. Поліційний характер державного апарату країни примушував навіть лояльних підданих вдаватися до протиправних дій для задоволення своїх насамперед культурних потреб. Втім, зміст заборонених видань свідчить про те, що читачі задумувалися про ширше коло проблем, щонайменше політичних і соціальних, хоч можливо поза якихось чітких ідеологічних переконань. Свідомі практики дворян щодо заборонених книг свідчать про тихий спротив владі, який врештірешт протиставляв людину державній системі, розхитував традиційну систему цінностей.

Подяка. Висловлюємо щиру вдячність працівникам бібліотек за сприяння у підготовці статті, а також членам редколегії журналу за консультації, надані під час підготовки статті до друку.

Фінансування. Автори не отримали фрінансової підтримки для дослідження, авторства та / або публікації цієї статті.

\section{Джерела та література:}

Darnton, R. (2010). Poetry and the Police: Communication Networks in Eighteenth-Century Paris. Cambridge, MA: Harvard University Press. 224 p.

Epsztein, T. (2005). Z piorem $i$ paletą: zainteresowania intelektualne $i$ artystyczne ziemiaństwa polskiego na Ukrainie w drugiej połowie XIX w. Warszawa: Neriton. $589 \mathrm{~s}$.

Kutyłowska, H. (2003). Wspomnienia z Podola (1898 - 1919). Warszawa: Czytelnik. 124 s. 
Айзеншток, И. (1939) Французские писатели в оценках царской цензуры. Литературное наследство, (33-34), 769-861.

Барвінок, О. (2014). Дворяни Подільської губернії в органах державного управління та станового самоврядування регіону (1793 - 1917 рр.) (автореф. дис. ... канд. іст. наук : 07.00.01). Миколаїв. 19 с.

Баринова, Е. (2006). Российское дворянство в начале XX века: социокультурный портрет. Самара. 379 c.

Брискман, М. А. (1935). Ф. И. Тютчев в Комитете цензуры иностранной. Литературное наследство, (19/21), 565-578.

Кароєва, Т. (2019). Регіональні родові бібліотеки початку XX ст.: до методики встановлення факту існування (на прикладі Подільської губернії). Рукописна та книжкова спадщина України, (23), 139-153. doi: https://doi.org/10.15407/rksu.23.139.

Кривошея, I. (1997). Еволюція дворянства Правобережної України наприкінці XVIII - початку XX cm. (на матеріалах Київської губернії) (автореф. дис. ... канд. іст. наук: 07.00.01). Київ. 19 с.

Курков, К. (2006). Российское дворянство в контексте модернизации в начале XX в. : экономический и социокультурный аспекты (автореф. дис... д-ра ист. наук: 07.00.02). Москва. $50 \mathrm{c.}$

Левицкий, О. (1906). Из жизни учебных заведений Юго-Западного края в 1840-х годах. Киевская старина, (XCIII), 70-78.

Патрушева, Н. Г. (сост.) (2013). Цензоры Российской империи, конец XVIII - начало XX века: биобиблиогр. справ. Санкт-Петербург. 480 с.

ПС3 - Полное собрание законов Российской империи (1825 - 1881). Собр. 2. Санкт-Петербург.

Соломонова, Т. Р. (2010). Книга як знаряддя збереження етнічної ідентичності поляками Поділля другої половини XIX - початку XX ст. Наукові записки Вінницького державного педагогічного університету імені Михайла Коцюбинського. Серія: Історія, (18), 328-331.

Темірова, Н. Р. (2003). Поміщики України в 1861-1917 рр.: соціально-економічна еволюція. Донецьк. 320 с.

Филатова, Т. В. (2000). Российское поместное дворянство в начале XX в.: организация, деятельность, попытки самоидентификации (автореф. дис... канд. ист. наук: 07.00.02). Москва. 26 с.

Шартье, Р. (2001). Культурные истоки Французской революции. Москва: Искусство. 256 с.

Шахрай, Т. О. (2009) Господарська, громадсько-політична та культурна діяльність дворян $i$ поміщиків Волині наприкінці XIX - початку XX cm. (автореф. дис. ... канд. іст. наук: 07.00.01). Черкаси. 20 с.

Эйдельман, Н. Я. (1984). Гериен против самодержавия. Секретная политическая история России XVIII u XIX веков u Вольная печать. Москва. 317 с. URL:http://vivovoco.astronet.ru/VV/PAPERS/NYE/DOLGO.HTM

Юдин, Е. Е. (2000). Русское дворянство накануне и в период первой мировой войны: Проблемы социального развития и политической деятельности (автореф. дис... канд. ист. наук: 07.00.02). Москва. 16 с.

\title{
Татьяна Кароева
}

Винницкий государственный педагогический университет имени Михаила Коцюбинского доктор исторических наук, доцент (Украина)

\section{Фрондерские настроения поместного дворянства Правобережной Украины второй половины XIX в. в призме книжныХ практик}

\begin{abstract}
Аннотация. Цель статьи. С модернизацией Российской империи поместное дворянство на протяжении второй половины XIX в. постепенно адаптировалось к новым социоэкономическим условиям и становилось социально активным, но не получило даже минимальных политических регуляторов для удовлетворения своих социальных, экономических и культурных потребностей до 1906 г., выборов в Государственную думу. Оно, как и все другие социальные группы империи, не могло фрормулировать свои политические требования, создавать политические организации, которые отстаивали бы их интересы. В то же время и до революционных событий 1917 г. дворянство продолжали считать опорой самодержавия, поэтому важно определить, было ли оно абсолютно преданным империи, существовали ли фррондерские настроения среди его представителей. Под фррондерскими настроениями определенной социальной группы здесь понимается негативизм, вызванный действиями власти, который реализуется скорее как сопротивление в сфрере культуры и не ведет к конфронтации с властью. Поместное дворянство рассматривается вне этнического происхождения его представителей.
\end{abstract}


Методология исследования предполагает использование книг как вещевых источников и историко-книговедческие методы анализа. Научная новизна. Для изучения пассивного сопротивления власти, традиционно малодоступного для изучения, проанализированы книжные практики (приобретение, распространение, использование и хранение книг) поместного дворянства. Выводы. Установлено, что на протяжении второй половины ХІХ в. помещики-дворяне Правобережной Украины имели фрондерские настроения. Полицейский характер государственного аппарата страны заставлял даже лояльных подданных прибегать к противоправным действиям для удовлетворения своих культурных потребностей. Их сознательная работа с запрещенными книгами свидетельствует о тихом сопротивлении власти, которое в конце концов противопоставляло человека государственной системе, раскачивало традиционную систему ценностей.

Ключевые слова: поместное дворянство, книжные практики, книга, книжная культура, родовые библиотеки, Правобережная Украина

\author{
Tetiana Karoyeva \\ Vinnytsia Mykhailo Kotsiubynskyi State Pedagogical University \\ Dr (History), Associate Professor (Ukraine) \\ Fronde-like sentiment of landed gentry of Right-Bank Ukraine \\ in the second half of the 19th century in the light of book-related practices
}

\begin{abstract}
The purpose of the article. In the process of modernization during the second half of the 19th century, landed gentry of the Russian Empire gradually adapted to new socioeconomic conditions and became more socially active, but they didn't get even minimal political regulators to meet their social, economic and cultural needs until 1906 elections to the State Duma. Like all other social groups of the empire, landed gentry have no could neither formulate their political demands nor create political organizations that would uphold their interests. At the same time, until the revolutionary events of 1917, the nobility was still considered the pillar of the autocracy, so it is important to determine whether it was absolutely committed to the empire, or was there Fronde-like sentiment among its representatives. Within the scope of this article Fronde-like sentiment of a particular social group refers to negativism caused by actions of the authorities, which is exhibited rather as a cultural resistance and does not lead to confrontation with the powers that be. The landed gentry is considered herein regardless of ethnicity of its representatives. Methodology of the study includes using of books as material sources as well as historical and bibliognostical methods. Scientific novelty. Bookrelated practices of the landed gentry (acquisition, distribution, use, and storage of books) have been analyzed in order to study the passive resistance to power, which traditionally isn't easily accessible. Conclusions. It has been ascertained that there was Fronde-like sentiment among landlords and noblemen of Right-Bank Ukraine during the second half of the 19th century. The police nature of the country's state apparatus concussed even loyal subjects to resort to unlawful actions in order to satisfy their cultural needs. Their deliberate practices related to forbidden books corroborate the existence of quiet opposition to the authorities, which ultimately opposed an individual to the state system and compromised the traditional value system.
\end{abstract}

Key words: landed gentry, book-related practices, book, book culture, ancestral libraries, Right Bank Ukraine

\title{
References:
}

Ayzenshtok, I. (1939) Frantsuzskie pisateli v otsenkakh tsarskoy tsenzury [French writers as per assessments of tsarist censorship]. Literaturnoe nasledstvo - Literary Heritage, (33-34), 769-861. [in Russian].

Barinova, Ye. (2006). Rossiyskoe dvoryanstvo v nachale XX veka: sotsiokulturnyy portret [Russian nobility in the forepart of the 20th century: social and cultural portrait]. Samara. $379 \mathrm{~s}$. [in Russian].

Barvinok, O. (2014). Dvorjany Podiljsjkoji ghuberniji $v$ orghanakh derzhavnogho upravlinnja ta stanovogho samovrjaduvannja reghionu (1793-1917 rr.) [Nobles of Podillia province in regional bodies of state administration and estate-specific self-government $(1793-1917)]$ (Extended abstract of Candidate's thesis). Mykolayiv. [in Ukrainian]

Briskman, M. A. (1935). F. I. Tyutchev v Komitete tsenzury inostrannoy [F. I. Tiutchev's activity in the Foreign Censorship Committee]. Literaturnoe nasledstvo - Literary Heritage, (19/21), 565-578. [in Russian].

Chartier, R. (2001). Kulturnye istoki Frantsuzskoy revolyutsii [Cultural origins of the French Revolution]. Moskva: Iskusstvo. $256 \mathrm{~s}$. [in Russian].

Darnton, R. (2010). Poetry and the Police: Communication Networks in Eighteenth-Century Paris. Cambridge, MA: Harvard University Press. 224 p. [in English]. 
Epsztein, T. (2005). Z piorem i paletą: zainteresowania intelektualne $i$ artystyczne ziemiaństwa polskiego na Ukrainie w drugiej połowie XIX w. Warszawa: Neriton. 589 s. [in Polish].

Eydelman, N. Ya. (1984). Gertsen protiv samoderzhaviya. Sekretnaya politicheskaya istoriya Rossii XVIII i XIX vekov $i$ Volnaya pechat [Herzen against the autocracy. Secret political history of Russia of the 18th and 19th centuries and the Free press]. Moskva. $317 \mathrm{~s}$. URL:http://vivovoco.astronet.ru/VV/PAPERS/NYE/DOLGO.HTM [in Russian].

Filatova, T. V. (2000). Rossiyskoe pomestnoe dvoryanstvo $v$ nachale $X X$ v.: organizatsiya, deyatelnost, popytki samoidentifikatsii [Russian landed gentry in the early 20th century: organization, activity, and attempts of self-identification] (Extended abstract of Candidate's thesis). Moskva. [in Russian].

Karoyeva, T. (2019). Reghionaljni rodovi biblioteky pochatku XX st.: do metodyky vstanovlennja faktu isnuvannja (na prykladi Podiljsjkoji ghuberniji) [Regional family libraries in the early 20th century: towards methodology of establishing the fact of existence (on example of Podillia province)]. Rukopysna ta knyzhkova spadshhyna Ukrajiny - Manuscript and Book Heritage of Ukraine, (23), 139153. doi: https://doi.org/10.15407/rksu.23.139 [in Ukrainian]

Kryvosheja, I. (1997). Evoljucija dvorjanstva Pravoberezhnoji Ukrajiny naprykinci XVIII - pochatku XX st. (na materialakh Kyjivsjkoji ghuberniji) [Evolution of nobility of Right-Bank Ukraine in the last part of the 18th - the forepart of the 20th centuries (on the basis of materials of Kyiv province)] (Extended abstract of Candidate's thesis). Kyiv. [in Ukrainian]

Kurkov, K. (2006). Rossiyskoe dvoryanstvo $v$ kontekste modernizatsii $v$ nachale $X X \quad v$. : ekonomicheskiy $i$ sotsiokulturnyy aspekty [Russian nobility in the context of modernization at the forepart of the 20th century: economical and sociocultural aspects] (Extended abstract of Candidate's thesis). Moskva. [in Russian].

Kutyłowska, H. (2003). Wspomnienia z Podola (1898-1919). Warszawa: Czytelnik. 124 s. [in Polish].

Levitskiy, O. (1906). Iz zhizni uchebnykh zavedeniy Yugo-Zapadnogo kraya v 1840-kh godakh [Passages of the history of educational institutions of the South-Western Territory in the 1840s]. Kievskaya starina - Kiev antiquity, (XCIII), 70-78. [in Russian].

Patrusheva, N. G. (ed.) (2013). Tsenzory Rossiyskoy imperii, konets XVIII - nachalo XX veka [Censors of the Russian Empire, the last part of the 18th - the forepart of the 20th centuries: biographical and bibliographic directory]. Sankt-Peterburg. $480 \mathrm{~s}$. [in Russian].

PSZ - Polnoe sobranie zakonov Rossiyskoy imperii (1825-1881) [Complete Collection of the Russian Empire Laws]. Sobr. 2. Sankt-Peterburg. [in Russian].

Shahraj, T. O. (2009). Ghospodarsjka, ghromadsjko-politychna ta kuljturna dijaljnistj dvorjan $i$ pomishhykiv Volyni naprykinci XIX - pochatku XX st. [Economical, socio-political and cultural activities of nobles and landed gentry of Volyn province at the end of the 19th - the forepart of the 20th centuries] (Extended abstract of Candidate's thesis). Cherkasy. [in Ukrainian]

Solomonova, T. R. (2010). Knygha jak znarjaddja zberezhennja etnichnoji identychnosti poljakamy Podillja drughoji polovyny $X I X$ - pochatku $X X$ st. [Book as an instrument used for preserving ethnic identity by Poles of Podillia province in the second half of the 19th - the forepart of the 20th centuries] Naukovi zapysky Vinnycjkogho derzhavnogho pedaghoghichnogho universytetu imeni Mykhajla Kocjubynsjkogho. Serija: Istorija - Scientific proceedings of Vinnytsia State Pedagogical University named after Mikhaylo Kotsiubynsky. Series: History, (18), 328-331. [in Ukrainian]

Temirova, N. R. (2003). Pomishhyky Ukrajiny v 1861 - 1917 rr.: socialjno-ekonomichna evoljucija. [Lords of the manor of Ukraine in 1861 - 1917: Social and economic evolution]. Doneczk. $320 \mathrm{~s}$. [in Ukrainian]

Yudin, Ye. Ye. (2000). Russkoe dvoryanstvo nakanune i $v$ period pervoy mirovoy voyny: Problemy sotsialnogo razvitiya $i$ politicheskoy deyatelnosti [Russian nobility on the eve of and during the First World War: Problems of social development and political activity] (Extended abstract of Candidate's thesis). Moskva. [in Russian]. 